January 2013

\title{
Collaboration as an Essential Tool in Information Literacy \\ Education 9-16: Context, Qualities and Implications
}

Samantha Godbey

San Jose State University, samantha@plip.com

Follow this and additional works at: https://scholarworks.sjsu.edu/ischoolsrj

Part of the Library and Information Science Commons

\section{Recommended Citation}

Godbey, S. (2013). Collaboration as an Essential Tool in Information Literacy Education 9-16: Context, Qualities and Implications. School of Information Student Research Journal, 2(2). https://doi.org/ 10.31979/2575-2499.020203 Retrieved from https://scholarworks.sjsu.edu/ischoolsrj/vol2/iss2/3

This article is brought to you by the open access Journals at SJSU ScholarWorks. It has been accepted for inclusion in School of Information Student Research Journal by an authorized administrator of SJSU ScholarWorks. For more information, please contact scholarworks@sjsu.edu. 


\title{
Collaboration as an Essential Tool in Information Literacy Education 9-16: Context, Qualities and Implications
}

\begin{abstract}
This article addresses the research question of how contemporary school librarians can best surmount the challenges of limited funding and high expectations. The author argues that in order to provide effective information literacy instruction, school librarians should increase collaboration with academic librarians. A review of the literature identifies numerous articles describing individual collaborations and lamenting information literacy skills gaps among college students. This article intends to serve as a call to action to school and academic librarians. This literature review explores the context for collaboration in libraries, discusses examples of school library collaborations, and examines the implications of various aspects of collaboration.
\end{abstract}

\section{Keywords}

information literacy, collaboration, school libraries

\begin{abstract}
About Author
Samantha Godbey graduated from San Jose State University with her teacher librarian credential and MLIS in May 2012. She also has a single subject teaching credential and M.A. in Education from UC Berkeley. Her research interests include information literacy instruction and reference in school and academic libraries. As of December 2012, she is Education Liaison Librarian at University of Nevada, Las Vegas.
\end{abstract}


The proliferation of electronic content and the development of new technologies are causing fundamental changes to the processes of reading and research, leaving many librarians curious and concerned about the future of the profession. In the midst of this transitional period, contemporary school librarians continue to face the challenges of limited funding and high expectations. Education and library funding continues to be cut, yet school librarians are tasked with coordinating efforts to educate children in information literacy so that they are educated consumers of information. Information literacy, the ability to "recognize when information is needed and have the ability to locate, evaluate, and use effectively the needed information," (American Library Association, 1989 ) is among the highest priorities in education. This article addresses the research question of how school librarians can continue to provide effective information literacy instruction despite the challenges of limited funding and high expectations.

In recent years, various organizations, from business to education, have turned to collaboration as a way of increasing profits and creating new opportunities for growth. Collaboration is a process that takes many forms in many organizations. This paper focuses on collaborations among librarians in academic settings, arguing that secondary school librarians, who are preparing a higher number of students than ever for postsecondary education, must collaborate with academic librarians. A review of the literature reveals numerous articles describing collaborative partnerships and lamenting information literacy skills gaps among college students. This article intends to serve as a call to action to school and academic librarians by consolidating information on library collaborations already taking place and providing guidelines for successfully entering into a collaborative relationship. This paper reviews the context for collaboration in libraries, discusses examples of school library collaborations, and explores several implications of collaboration.

\section{The Context for Collaboration}

\section{Emphasis on Information Literacy Instruction}

Hull and Taylor (2003) note that in the early 1990s, the main concern regarding student access to technology was the lack of computers, but by the following decade the main concern had become "students' lack of proficiency in using technological resources to access relevant information" (p. 85). Recommendations from the American Association of School Librarians (AASL) and American Library Association (ALA) are in line with this need for information literacy instruction, from the 1998 publication of Information Power, which defined information literacy and laid out a plan for instruction, to the 2007 
release of the AASL Standards for the 21-st Century Learner, which emphasize the school librarian's commitment to information literacy education.

\section{Gaps in Skills}

Despite the publication of standards, however, the reality of the gap between the skills expected from high school graduates and the skills actually demonstrated by entering college students reveals a need for substantial change in information literacy instruction and increased communication between secondary and postsecondary schools. Hull and Taylor (2003) note that due to "the pervasiveness of the knowledge gap, there needs to be a more systematic effort in both the fields of education and librarianship to better prepare students for college-level research" (p. 84) and that this knowledge gap is becoming more problematic as the amount of accessible information increases. Gordon (2002) echoes Hull and Taylor's concerns about student skills, noting that first-year college students either have not been exposed to or have not retained the research skills essential to collegiate success. Gordon surveyed a group of graduate students in master's and doctoral programs, and even these students revealed a lack of comfort with basic research skills such as the use of Boolean operators and the effective searching of electronic databases. Polls of secondary school library media specialists (SLMS) reinforce these concerns. For example, in their survey of secondary SLMSs, Islam and Murno (2006) found that fewer than $38 \%$ of the school library media specialists polled believed their students were acquiring adequate information literacy skills by the time they graduated from high school (p. 505).

\section{Increase in Post-Secondary Enrollment}

The need for adequate secondary school preparation for collegiate-level work has become increasingly pressing as the number of students progressing from high school to college has increased. Fifty years ago, only $34 \%$ of students graduated from high school and 6\% earned bachelor's degrees (Hess, 2008), but in the present day college is no longer an institution reserved for the elite. Instead, college is increasingly considered an expected extension of a high school education. As the number of students who expect to continue their educations past secondary school increases, so does the need for deliberate work in addressing this knowledge gap between grades twelve and thirteen. 


\section{Collaboration in Education}

One of the most significant trends guiding collaboration in schools is the P-16 movement. Beginning in the 1990s, the P-16 movement was developed in response to the perceived need for a fluid educational experience from preschool through college. Variations on P-16 such as K-20, which goes up to grade "20" to indicate possibilities for learning beyond college, share the same emphasis on easing the educational transitions for students from youth to early adulthood. In his discussion of the P-16 movement, Hess (2008) argues that the divisions between primary, secondary, and postsecondary schools are "arbitrary" and "synthetic" (p. 511). The P-16 movement hopes to remedy the gaps that have developed as a result of treating the different stages in a child's education as completely distinct components.

P-16 initiatives include the creation and implementation of P-16 data systems that allow educators to track student achievement throughout their academic careers (Chamberlin \& Plucker, 2008). Hess (2008) identifies Florida's K-20 Education Data Warehouse, Indiana's Core 40 high school curriculum, and California's Academic Partnership Program as some of the most constructive developments in the P-16 education movement.

Chamberlin and Plucker (2008) note that most P-16 systems were initiated by state departments of Education or institutions of higher learning. P-16 committees include educators, business and community leaders, and representatives from state agencies. As such, these committees are strong examples of cross-sectoral collaboration.

According to Nebraska's P-16 Initiative (n.d.), 30 states have some sort of P-16 initiative, though not all are codified by law. P-16 legislation has formalized some collaborations that were in already in existence. For example, the 1995 Public Education/Higher Education Coordinating Group became the Texas P-16 Council after the passing of legislation (Chamberlin \& Plucker, 2008). In Florida, earlier P-16 efforts became law with the passing of the 2000 Education Governance Reorganization Act, which established an official K-20 education code (Chamberlin \& Plucker, 2008).

\section{The Trend of Collaboration in Libraries}

Collaboration is not a new concept in the library world. Borthwick (2001) defines educational partnership as "a process that brings together members (e.g. institutions, organizations, and agencies) and resources to produce outcomes directed to the enhancement of education" (p. 35). Partnerships are "dynamic and complex interagency relationships" (p. 36). This process of bringing together members and resources has manifested in numerous ways in different library 
contexts. For example, collaboration has filled gaps in funding and staffing (Woolls, 2001). Public libraries are partnering with communities and businesses to increase funding and extend community outreach, and developments in technology have led to new forms of collaboration.

There is extensive literature about library consortia that enable the sharing of resources. This practice has been invaluable to academic libraries in the United States that take advantage of technology in order to provide shared cataloging, reference, and access to electronic resources (Webster, 2006; Kohl \& Sanville, 2006) and equally invaluable to libraries in locales such as rural India (Laxman Rao, 2006). Webster (2006) argues that the developments in technology have led to more "connected and interdependent" libraries. Collaborative resources such as the Ontario School Curriculum Resource, developed by a consortium of school boards, academic libraries, and public libraries, are evidence of this interconnection (Borek, 2008). These consortia tend to focus on accessibility of resources, which can include the sharing of expertise such as reference services or curriculum materials, but in general, they focus more on the sharing of data than expertise. Their emphasis is not on the development of interdisciplinary projects that will be required to meet students' information literacy education needs.

Collaboration and School Libraries

School partnerships increased in the late 1980s, with many universities forming partnerships with local schools to assist in teacher training (Borthwick, 2001). School partnerships have continued to serve an important function in education reform. Collaboration plays a central role, along with leadership and technology, in Information Power, the American Association of School Librarians' 1998 declaration of defining principles and standards for the profession.

\section{Intrainstitutional Collaboration}

Collaboration within institutions is not unusual. As members of a faculty working with other educators in the same institution, librarians are poised to participate in collaborations with colleagues. The literature supports the existence of a strong history of librarian-faculty collaboration, as in Ercegovac's (2003) case study of collaboration between a science teacher and librarian. Another example is evidenced by the structuring of the Georgia State University Library staff. The majority of librarians serve as liaisons to academic departments, working directly with those departments in collection development, providing library instruction and reference, and serving as department advocates (Hull \& Taylor, 2003). The same is true of the University of Nevada, Las Vegas. 
School-Public Library Collaboration

Collaboration between school libraries and public libraries also has a strong tradition. Dual libraries that serve an academic community and the public have arisen as one example of these collaborations. Woolls (2001) argues that much of the collaboration between schools and public libraries at the time of writing involved districts without professional librarians. In essence, public librarians served as part-time replacements for SLMSs. This type of cooperation addresses a need and is a far better alternative to leaving schools and students without the expertise of any professional librarians at all. However, it is often a substitution for a school librarian, whereas a collaboration between an SLMS and public librarian might generate innovative ways of addressing student achievement.

Even in active collaborations between school and public libraries, differences between school and public libraries require careful consideration. F. Harris (2003) discusses the differences between schools and public libraries, particularly in how they conduct information transactions. In public libraries, the user is the person who decides how much assistance is needed, whereas in school libraries, "a reference transaction is also a teaching transaction" (p. 216). F. Harris argues that SLMSs take a more active role in determining how much help to give a student and in guiding the student to an understanding of the assignment and the information need. While exposing students to different kinds of libraries introduces them to different kinds of information transactions, increased collaboration with public libraries may not actually improve student readiness for academic research in college.

Gilton (2008) also argues that gaining skills in a public library does not translate to academic library skills, pointing out the different information systems used in each and the fact that academic libraries are generally much larger than public libraries. Furthermore, Gilton notes that, although public librarians have a long history of instructing patrons in information use, that instruction has been informal and indirect, in contrast to the direct instruction that takes place in school and academic libraries.

Models of School-University Collaboration

A wealth of literature exists on the concept of school-university collaboration. For example, Ravid and Handler (2003) identify four distinct models of school-university collaboration. The first is the PDS (Professional Development School) model, in which a university collaborates with a professional development school. The PDS model emphasizes using the collaborative school as a site for teacher training. A collaboration in the 
Consultation Model consists of a small group of university faculty working with one or several teachers in a school. The third model is the One-to-One Collaborations Model, with two participants, one from a university and the other from a school, acting as equal partners and conducting a research project together. Finally, the fourth model is the Umbrella Model, in which multiple collaborations take place under the auspices of one larger umbrella organization. Each project team has university and school educator participants, as well as other stakeholders from the organization.

Collaborations also differ based on who initiated the collaboration and for what reason. Borthwick, Stirling, Nauman, and Cook (2003) note the difference between voluntary and mandated partnerships. Some districts have mandated partnerships for teachers in low-achieving schools as a way of improving student achievement. In studying the perceptions of participants in a number of collaborations between a Chicago university and several Chicago public schools, half of which were voluntary and half of which were required for schools on probation, Borthwick et al. found that participants in mandated partnerships were more focused on short-term goals and less interested in potential long-term benefits of collaboration. When participation was mandated, participants focused on short-term goals in order to meet the specific requirements of the mandated collaboration, rather than exploring the full possibilities for the collaboration that had been established.

Often collaboration is impromptu and informal. In Lonsdale and Armstrong's (2006) survey of secondary and university librarians in the United Kingdom, they discovered that the majority of collaborations tend to be impromptu. These ad hoc collaborations sometimes evolve into more formal systems, such as the Georgia State University Library program that began as a result of informal conversations between two academic librarians and then developed into an extensive project (Hull \& Taylor, 2003).

\section{Examples of SLMS-Academic Library Collaboration}

A number of collaborative efforts between school libraries have taken place or are currently underway and can be examined for lessons on collaboration. For example, a research partnership such as the one described by Harada (2005), in which a university partner studied teacher-SLMS collaboration, is an example of a collaboration in the Consultation Model. The university partner observed instruction and conducted interviews for several years in order to develop research on existing collaborations within the secondary school in the study.

As the Georgia State University Education and Communications liaison librarians, Hull and Taylor (2003) co-taught a course to pre-service SLMSs in the College of Education's Library Media Technology Program. This type of direct 
instruction to students training to be SLMSs increased the students' awareness of the need for information literacy instruction and helped the students and their instructors to develop strategies for use with K-12 students. When the pre-service SLMSs began to work in area schools, the program led to ongoing collaboration when the academic librarians visited their former students at their school sites.

The Georgia State University Library course (Hull \& Taylor, 2003) demonstrates collaboration in several ways. First, this is an example of intralibrary collaboration between the two librarians as co-teachers. Secondly, the course demonstrates intraorganizational collaboration between the university librarians and members of academic department faculty. Finally, because the collaboration continued once the former students began their careers as school media specialists, the program also illustrates interorganizational collaboration between academic librarians and school media specialists. In this way, a collaboration that began informally as a conversation about a professional development exercise eventually led to collaboration in the style of the Consultation and One-to-One Collaborations models.

Nichols, Spang, and Padron (2005) examine the extensive collaboration at Wayne State University, including a continuing education course in information literacy for K-12 teachers and librarians, on-site information literacy workshops to K-12 educators that had been collaboratively developed by K-12 educators and university librarians, and an information literacy course for pre-service SLMSs. In the 1990s, Brooklyn College's Collaborative Library Project provided research instruction and access to collections for a semester (Evans, 1997) to a group of high school students, their teachers, and their school librarians. In the Brooklyn College project as well as the project at Wayne State University (Nichols, 1999; Nichols, 2001), collaboration with surrounding high schools arose from an awareness that the undergraduates at these universities predominantly come from the surrounding areas. Therefore, library-academic library collaboration was seen as an investment in the future students of the universities.

Essential Elements of Successful Collaboration

In their analysis of studies of collaboration between universities and K-12 schools, Kersh and Masztal (1998) define a successful collaboration as "making a sustained and lasting positive effect" (para. 2). In their analysis of various studies of collaborations, in which each collaboration examined had lasted a minimum of three years, Kersh and Masztal identify a number of essential components to successful collaboration. A look at Kersh and Masztal's studies as well as others generates the following list of elements that will enable a collaboration to make a sustained and lasting positive effect. 
Clearly defined, practical goals. Kersh and Masztal (1998) stress the importance of writing a long-range development and management plan to develop a "shared vision" and documenting the plan to achieve that vision. The development plan should carefully assess the resources required before the collaboration begins. This plan must involve realistic goals and an awareness that change is a lengthy process. This goal "must reflect a genuine problem facing the school" (Kersh \& Masztal, 1998) and have specific practical application (Nichols, 1999). For example, projects often focus on either honors students (Evans, 1997) or low-achieving students because of the perceived need for college-related experiences and instruction for each group. The honors students are seen as likely to attend college, whereas low-achieving students receive a lot of attention as educators try to motivate those students and increase their skills.

Clearly defined leadership structure and participant roles. The development of a collaborative plan must also address the leadership structure and define participant roles. Since collaborations involve participants in different positions from different organizations, leadership roles can create tension in the group. Leadership issues have been noted in collaborations (Borthwick et al., 2003), particularly in one-to-one collaborations, since neither partner has authority over the other in case of conflict or one partner not fulfilling their responsibilities. Kersh and Masztal (1998) noted that administrators in particular are placed in an uncomfortable position in collaborations since they must "accommodate the administrative expectation of the principal as a strong leader while simultaneously releasing 'power' to teachers" in order to participate collaboratively (Component 3: The School section, para. 3). Early establishment of group norms and participant roles can help prevent confusion and disharmony.

Equality. Successful collaborations treat participants as equals, each with expertise and skills to contribute to a project. Kersh and Masztal note that university educators must act as "inquirers rather than as experts leading the reform" (1998, Component 4: The University section, para. 1). They also point out that teachers are generally not trained to be leaders, so sometimes they are not comfortable with taking leadership roles or resisting another participant who is too comfortable with doing so. Therefore, negotiating an equal relationship between collaborators can sometimes be challenging and must be deliberately maintained.

Genuine personal commitment from all parties. All members of the collaborative team must want to participate. Borthwick et al. (2003) warn schools about the potential negative impact of mandating partnerships, rather than keeping 
them voluntary, because doing so can create "a climate of distrust or even fear, particularly on the part of teachers" (p. 358).

Administrative support. The necessity for administrative support from both school and university administrators is a recurring theme in the literature. For example, in response to a 2002 nationwide survey that showed that $66 \%$ of respondents had supportive principals, Islam and Murno (2006) conducted their own study on SLMS-administrator relationships and found that a majority of respondents felt a noticeable lack of administrative support for their work as SLMSs. Nonetheless, administrative support is imperative if participants are to acquire the resources they need to achieve their goals. Some of the most successful collaborations involve administrators as active participants. Kersh and Masztal argue that "For any sustained partnership, the principal must continuously, vigorously, and openly support the partnership" (Component 3: The School section, para. 3).

Evaluation. F. Harris (2003) notes that standards are only as meaningful as their implementation, and Hess (2008) echoes this sentiment. Hess argues that the development of standards is not enough to manifest change; what really matters is how those standards are implemented by teachers, schools and colleges. While collaboration is an excellent opportunity to explore effective and innovation instructional strategies, it must be paired with evaluation. Kersh and Masztal (1998) observe that few studies focus on collaborations and their failings, noting that it is in the universities' and schools' best interest to "put the best face possible on the project" (Learning from Collaboration section, para. 1) in order to maintain justification for funding and time spent. Furthermore, participants benefit from collaboration and provide valuable data for other educators.

Communication. As in any relationship, communication is seen as a key component of any successful collaboration, whether in consortia (Borek, Richardson, \& Lewis, 2008), P-16 initiatives (Chamberlin, 2008) or K-12 university partnerships (Kersh \& Masztal, 1998). Members must communicate with one another about progress toward the collaborative goal and feel empowered to communicate concerns and ideas about the project. In some collaborations, there is a real or perceived resentment on the part of teachers toward an external partner (Borthwick et al., 2003), and communication is essential to dealing with these emotions before they interfere with the project. 
Advantages and Disadvantages of SLMS-Academic Librarian Collaborations

Potential Disadvantages

Lonsdale and Armstrong (2006) found that the university librarians in their study looked very favorably on collaboration, while others have noted the potential disadvantages, particularly for university librarians (e.g. Evans, 1997). For example, the time-consuming nature of collaboration can be seen as a reason not to collaborate (Hull \& Taylor, 2003), or a school-academic library collaboration in which high school students are given access to the academic library can lead to serious demands on the academic library's resources, to the detriment of other patrons.

Other concerns stem from some of the very qualities that make collaborations effective. Over the course of collaboration, for example, participants become a learning community who know one another well. This can make collaborations more pleasurable and interesting and increase a sense of trust between participants. However, too often, once formed, a collaboration becomes dependent on the individuals involved, so projects are delayed or collaborations are dissolved when individuals leave their positions (Nichols, 1999; Nichols et al., 2005), leading to wasted effort and resources, and frustration and disappointment among the other participants. In a collaborative effort between an academic librarian and a school, if one of the librarians leaves for a different school, or the administrator who supported the project is promoted to a different position, the project could be jeopardized.

\section{Advantages of SLMS-Academic Collaboration}

Despite these potential negative sides of collaboration, however, there are also significant advantages for SLMSs and academic librarians. Both SLMSs and academic librarians stand to gain useful insight into their own teaching practices through collaboration. Cahoy (2002) points out that "Learning about the needs of students in grades above or below your focus can help highlight the skills most needed by your students" (p. 15).

Benefits to SLMSs. Collaboration with academic librarians offers a number of advantages to school librarians, such as opportunities for professional development. In Evans' (1997) study of the Brooklyn College project, for example, school teachers and librarians were not up-to-date on current research materials, since current research is not emphasized in school settings. The project provided an opportunity for teachers and librarians to gain valuable research skills that they could share with their students. Collaborations with academic libraries 
also provide school librarians access to additional resources, since academic libraries have much larger collections than school libraries (Borthwick et al., 2003). As previously noted, since teachers usually do not receive specific training as leaders, collaborations provide opportunities for SLMSs to develop and become aware of their leadership skills (Kersh \& Masztal, 1998). Furthermore, Nichols, Spang, and Padron (1999) found that K-12 collaborative participants felt that having university partners lent more "credibility" to their projects, as did the involvement of administration.

Benefits to academic librarians. Although largely unreported in the past (Borthwick et al., 2003), collaboration with school librarians has many benefits for academic librarians. First of all, collaborative projects generate opportunities for research and publishing, as noted in Harada (2005) and Kersh (1998). More importantly, these types of projects keep academic librarians informed about information literacy instruction that is taking place in lower grades (Hull \& Taylor, 2003), which will help them understand better how to assess and meet the needs of their own students. Increasing secondary students' exposure to academic libraries will help to ease the transition between high school and college. Teachers can contribute to university instruction as well by contributing their firsthand knowledge of education and providing "opportunities for the university partner to be reminded of the world that teachers face daily" (Kersh \& Masztal, 1998, Component 2: The Nature of Partnerships section, para. 7). W. Harris, Cobb, Pooler, and Perry (2008) make the significant comment that educators in P-12 schools have considerably more experience with "standards, assessment, and the politics of accountability" (p. 496).

Implications for Future Collaboration

School and academic librarians have a responsibility to the students they serve to help educate them in information literacy. Librarianship as a profession is changing, but this should be a time of excitement about the future. Through collaboration with academic librarians, school librarians can expand their resources and expertise. They can gain insight from another professional who has an idea of the skills students will need in grades 13 to 16 , where the school librarian's expertise fades. It is an ideal opportunity for collaboration, where each partner's expertise complements the other. School and academic librarians share expertise on the same subject but from different perspectives. Only by embracing new perspectives can school librarians challenge themselves to develop innovative ways of educating their students. Hess (2008) warns against merely "appending" reforms such as collaboration and viewing them as the "outer limits of potential changes" (p. 512). Collaboration is an exceptional opportunity to 
develop expertise and expand support for our students, as long as librarians are deliberate and informed about the process.

\section{References}

American Association of School Librarians. (2007). Standards for the 21-st century learner. Chicago: American Library Association.

American Association of School Librarians and the Association for Educational Communication and Technology. (1998). Information power: Building partnerships for learning. Chicago: American Library Association.

American Association of School Librarians and the Association of College and Research Libraries. Task Force on the Educational Role of Libraries. (2000). Blueprint for collaboration. Chicago: American Library Association.

American Library Association. (1989). Presidential Committee on Information Literacy. Final report. Chicago: American Library Association.

Borek, D., Bell, B., Richardson, G., \& Lewis, W. (2006). Perspectives on building consortia between libraries and other agencies. Library Trends, 54(3), 448-462.

Borthwick, A. C. (2001). Dancing in the dark? Learning more about what makes partnerships work. In R. Ravid \& M. Handler (Eds.), The many faces of school-university collaboration (pp. 23-41). Englewood, CO: Libraries Unlimited.

Borthwick, A. C., Stirling, T., Nauman, A. D., \& Cook, D. L. (2003). Achieving successful school-university collaboration. Urban Education, 38(3), 330371.

Cahoy, E. (2002). Will your students be ready for college? Connecting K-12 and college standards for information literacy. Knowledge Quest, 30(4), 12-15.

Chamberlin, M., \& Plucker, J. (2008). P-16 Education: Where are we going? Where have we been?. Phi Delta Kappan, 89(7), 472-9. 
Ercegovac, Z. (2003). Bridging the knowledge gap between secondary and higher education. College \& Research Libraries, 64(1), 75-85.

Evans, B. (1997). Building bridges between New York City public high schools and a college: The cooperative library project. Research Strategies, 15(2), 89-99.

Gilton, D. (2008). Information literacy as a department store: Applications for public teen librarians. Young Adult Library Services, 6(2), 39-44.

Gordon, C. (2002). A room with a view: Looking at school library instruction from a higher education perspective. Knowledge Quest, 30(4), 16-21.

Harada, V. (2005). Librarians and teachers as research partners: Reshaping practices based on assessment and reflection. School Libraries Worldwide, 11(2), 49-72.

Harris, F. (2003). Information literacy in school libraries: It takes a community. Reference \& User Services Quarterly, 42(3), 215-23.

Harris, W., Cobb, R., Pooler, A., \& Perry, C. (2008). Implications of P-16 for teacher education. Phi Delta Kappan, 89(7), 493-6.

Hess, F. (2008). Making sense of the P-16 push. Phi Delta Kappan, 89(7), 51114.

Hull, T., \& Taylor, N. (2003). Crossing three bridges: Linking librarianship and teaching across the P-16 educational continuum. Reference Librarian, 40(83/84), 83-96.

Islam, R., \& Murno, L. (2006). From perceptions to connections: Informing information literacy program planning in academic libraries through examination of high school library media center curricula. College \& Research Libraries, 67(6), 492-514.

Kersh, M., \& Masztal, N. (1998). An analysis of studies of collaboration between universities and K-12 schools. The Educational Forum, 62(3), 218-25. 
Kohl, D. F., \& Sanville, T. (2006). More bang for the buck: Increasing the effectiveness of library expenditures through cooperation. Library Trends, 54(3), 394-410.

Laxman Rao, N. (2006). Knowledge-sharing activities in India. Library Trends, 54(3), 463-484.

Lonsdale, R., \& Armstrong, C. (2006). The role of the university library in supporting information literacy in UK secondary schools. Aslib Proceedings, 58(6), 553-569.

Nebraska's P-16 Initiative: A statewide effort to improve student success and boost the economy. History. (n.d.). Retrieved from http://p16.nebraska.edu/history.html

Nichols, J. (1999). Building bridges: High school and university partnerships for information literacy. NASSP Bulletin, 83(605), 75-81.

Nichols, J. (2001). Sharing a vision: Information literacy partnerships (K-16). College \& Research Libraries News, 62(3), 275-7, 285.

Nichols, J., Spang, L., \& Padron, K. (2005). Building a foundation for collaboration: K-20 partnerships in information literacy. Resource Sharing \& Information Networks, 18(1/2), 5-12.

Ravid, R., \& Handler, M. (2001). Models of school-university collaboration. In R. Ravid \& M. Handler (Eds.), The many faces of school/university collaboration: Characteristics of successful partnerships (pp. 3-10). Englewood CO: Libraries Unlimited.

Webster, P. (2006). Interconnected and innovative libraries: Factors tying libraries more closely together. Library Trends, 54(3), 382-393.

Woolls, E. (2001). Public library-school library cooperation: A view from the past with a prediction for the future. Journal of Youth Services in Libraries, 14(3), 8-10. 